\title{
THE IMPLEMENTATION OF DISASTER MITIGATION PLAN THROUGH STRUCTURAL FUNCTIONAL APPROACH
}

\author{
Muhammad Fedryansyah, Herijanto Bekti and Ramadhan Pancasilawan
}

Faculty of social and politic sciences, Universitas Padjadjaran, Jl. Raya Bandung-Sumedang KM. 21 Jatinangor E-mail:m.fedryansyah@unpad.ac.id., herijanto.bekti@unpad.ac.id., Ramadhan.pancasilawan@unpad.ac.id

\begin{abstract}
Pagerwangi Village is an area prone to natural disasters in West Bandung Regency. Also the geographical location is entered in the red-fault zone of the Lembang. So in the predictions will be one of the affected areas due to the tectonic earthquakes originating from the fault of the Lembang. Disaster management programs have been conducted by the Government along with other parties such as educational institutions and community groups. The study aims to analyse how the implementation of disaster mitigation through a functional structural approach or social balance theory of Talcott Parsons. The approach used on this studies is descriptive qualitative. The results showed that there were barriers in the system of functional structural approaches to disaster mitigation in the area of the Pagerwangi village of the four aspects namely integration, adaptation, latency and goal attaintment. These obstacles occur from one aspect, which affects other aspects.
\end{abstract}

Keywords: Disaster Prevention; Functional Structures; Social Balance Aspects.

\section{IMPLEMENTASI PERENCANAAN MITIGASI BENCANA MELALUI PENDEKATAN STRUKTURAL FUNGSIONAL}

\begin{abstract}
ABSTRAK. Desa Pagerwangi merupakan wilayah rawan bencana alam di Kabupaten Bandung Barat. Juga letak geografisnya masuk dalam zona merah sesar lembang. Sehingga di prediksi akan menjadi salah satu wilayah terdampak akibat gempa bumi tektonik yang berasal dari patahan sesar lembang. Program penanggulangan bencana sudah dilakukan oleh pemerintah bersama dengan pihak lain seperti instansi pendidikan dan kelompok masyarakat. Penelitian ini bertujuan untuk menganalisis bagaimana implementasi mitigasi bencana melalui pendekatan Struktural Fungsional atau teori Keseimbangan sosial Talcott Parsons. Metode yang digunakan dalam penelitian yaitu kualitatif deskriptif. Hasil penelitian ini menunjukkan bahwa terdapat hambatan-hambatan dalam sistem pendekatan struktural fungsional pada mitigasi bencana di wilayah desa Pagerwangi dari empat aspek yaitu Integrasi, adaptasi, pola pemeliharaan, dan pencapaian tujuan. Hambatan tersebut terjadi dari salah satu aspek sehingga berdampak pada aspek lainnya.
\end{abstract}

Kata kunci: Penanggulangan Bencana; Struktural Fungsional; Aspek Keseimbangan Sosial.

\section{INTRODUCTION}

Catastrophic events cause unsafe conditions and threaten the survival of human beings. It is characterized by the death of victims, injuries, environmental damage, property loss and psychological impacts, limitation of access to housing, limited health access, exacerbate the economic situation, the difficulty of obtaining a decent sanitation, victims become homeless as well as a factor in the cause of poverty. (Wu et al, 2019; Kaban et al, 2019; Karashima, 2019; Moser and Felton, 2007; World Bank, 2016; Duncan et al, 2018; Widayatun and Fatoni, 2013; Ramli, 2010). The impact caused by disasters requires handling efforts through a series of disaster risk reduction activities.

Further, efforts to reduce the risk caused by disasters can be done by preparing disaster mitigation activities. According to Irawan (2007) Operational mitigation is an effort to minimize the fall of casualties and lost or damaged assets and property, either through disaster mitigation efforts (prevention, enhancement of preparedness) or efforts to reduce vulnerability (physical, material, institutional social, behavioral or attitude). This was reinforced by a study conducted by Shreve and Kelman (2014), Dzulkarnain et al, (2019) which shows that disaster mitigation effectively can save human life, reduce environmental damage, and economic losses. Such mitigation is embodied in the form of opportunities to gain education, training, and skills improvement in order for them to have the knowledge and capacity to deal with disasters. Thus people are able to adapt and have readiness in the event of a disaster that threatens their survival.

Disaster mitigation may be completed with the event, particularly structural and non structural (Coppola, 2006). Structural mitigation is described as a danger discount attempt finished thru creation or bodily environmental alternate thru the utility of engineering solutions. While non-structural mitigation is described as a degree that reduces danger thru amendment in human behaviour or herbal tactics with out requiring the usage of engineering structures.

The effort to implement disaster mitigation is done to communities that are vulnerable to disaster events. The main objective of disaster mitigation is to increase the resilience of communities. Resiliency is the primary capacity of the community to endure and recover from the threat of disaster (Yoon 2015). Later, Norris et al (2008) added that resiliency is also related to the relationship between social and environmental situations that can represent the capacity of individuals or communities to face external threats as a consequence of social, political and ecological changes.

Then, the efforts to increase capacity or resilience of the community through the mitigation that is imposed 
by various parties. The impact of natural disasters can be a material loss even psychological-traumatic effect on the victim. One of the authorities is efforts in minimizing the effect is to enhance the preparedness of groups withinside the face of herbal disasters. The procedure involves various parties and is aligned with responsibility and authorization.

One of the vulnerable areas of disaster is West Bandung Regency. West Bandung region, especially the Pagerwangi village in the red zone of the Lembang. Namely a critical zone against earthquakes due to fault several years ago. The stretch of fault covers the vital area of the population. The tectonic earthquake occurred in the year $60 \mathrm{BC}$ and in the 15th century (https://www. ayobandung.com/read/2019/08/07/59915/lipkhas-gempawarga-bandung-desak-sosialisasi-potensi-gempa-sesarlembang)/. It is marked that the emergence of largescale earthquakes can come in the period that cannot be estimated while the Lembang fault has a big tendency to the emergence of earthquakes.

Landslides also often occur several times in the near term. The latest is a landslide in the Punclut region to inhibit traffic flow (https://www.republika.co.id/berita/nasional/ daerah/19/01/10/pl3sin423-tebing-punclut-longsor-bpbdbandung-barat-usulkan-perbaikan). Disaster risk programs have been conducted by the Government, such as disaster response simulation, installation of disaster signs and socialization of disasters in the village group. https://www. ayobandung.com/read/2019/08/07/59925/lipkhas-gempadesa-pagerwangi-cegah-dampak-sesar-lembang).

Seeing the phenomenon, according to Pramono (2016) if disaster management strategies become a reference in the response of human behaviour or social group in the face of a disaster threat becomes more effective, then the strategy needs to be developed and applied to be a part of human life or a group experiencing a threat of disaster in daily life. Pramono skew to make disaster management as a preventive action in the aspects of daily life.

Preventive action is a referral action from experts on a thing that is considered to cause chaos or chaos. Disaster mitigation is one of them. Regardless, taking preventive measures requires suitability of various aspects. Readiness, acceptance and adjustment. To achieve the goal that is expected, is the fulfillment of functions from various sides that intersect. Then it can be said that to accomplish a purpose, there are systems that meet each other. This avoids the failure of preventive procedures so that any element of society can complement each other to achieve a common goal.

Regarding the structures involved, Sanyoto (2014) stated that the community version of catastrophe mitigation, is characterised with the aid of using the cooperation that has been hooked up among the catastrophe control network organization Pagerwangi Village with numerous parties, which includes with the geological Agency/PVMBG. From the cooperation is then reached an settlement and dedication to cooperation with the authorities corporations withinside the efforts of catastrophe mitigation.

Components of these systems are mutually involved in fulfilling their functions to achieve a common goal regarding disaster response measures. However, the phenomenon found was the ignorance of society on the Taking of action when the earthquake occurred. The community has a knowledge of the potential for large earthquakes, but does not know the action to be done. This is because the people of Pagerwangi village did not get the socialization of disaster risk and preparedness training. (https://www.ayobandung.com/read/2019/08/07/59915/ lipkhas-gempa-warga-bandung-desak-sosialisasi-potensigempa-sesar-lembang).

Furthermore, the ignorance of people in anticipating and performing acts of preparedness will be a disaster understood as a form of malfunctioning or misrepresentation of existing systems. Parsons (1970) said it as an imbalance of the Community system that because of the existing system of functions to balance the process of disaster preparedness in the community.

The four important elements according to Parsons, (1970) are:

1. Integration, There is a device with a view to modify family members among structures. The characteristic of a device have to be capable of keep the general coordination of the device.

2. Adaptation, Every social device have to be capable of receive modifications from each out of doors and inside. This is in order that humans can retain to evolve to the environment.

3. Pattern-Maintenance, For all structures to be balanced, want motivation to keep the stability. It takes a sample to keep stability and control troubles arising. It may be achieved with the department of roles, offers and motivation. Thus, it's miles important to emphasise or keep the characteristic of every device to help the sustainability of the device.

4. Goal-Attainment, The advent of a device is to gain a not unusualplace goal. There are gear or devices used to gain those objectives.

Research related to disaster mitigation is usually done to see the process of activities conducted, evaluation and approach used (Wu et al, 2019; Kaban et al, 2019; Karashima, 2019; World Bank, 2016; Duncan et al, 2018; Guinet et al, 2017; Chacko et al, 2016; Asri et al, 2016; Muricho, 2018; Rajeev et al, 2019; P, 2020; Chou et al, 2017; Pancasilawan, 2020). As for the study of the system that has a role in disaster mitigation is still not much found. Therefore, this article aims to describe the function of every aspect of disaster mitigation efforts using the Parson approach (1970). Then, analysing disaster mitigation efforts based on a functional structural approach to describe the catastrophic system of disasters conducted in Pagerwangi village. 


\section{Disaster mitigation}

Disaster mitigation is blanketed in a chain of catastrophe control sports. Disaster control is a group of guidelines and administrative choices and operational sports associated with diverse levels of all degrees of catastrophe. (UNDP, 1992). In general, in general, catastrophe control sports may be divided into 3 major sports, which can be pre-catastrophe sports that consist of preventive, mitigation, preparedness, and early caution sports; Activities withinside the occasion of a catastrophe that consists of emergency reaction sports to alleviate brief suffering. Such as seek and rescue (SAR) sports, help and evacuation and; Post-catastrophe sports that consist of recovery, rehabilitation and reconstruction sports.

Disaster mitigation is included in pre-disaster activities. Disaster mitigation itself is essentially understood as actions undertaken to reduce or relieve all impacts arising from disasters (Cobourn, et.al, 1994). In other words, disaster mitigation is an effort to anticipate potential damage arising from good disasters caused by natural factors and human factors. In the process of disaster management, disaster mitigation is a strategic step, because with the implementation or improvement of positive mitigation efforts can potentially avoid people from possible fall casualties or damage to property or physical or social vulnerabilities.

Further, catastrophe mitigation may be completed in ways, particularly structural and non-structural (Coppola, 2006). Structural mitigation is described as a chance discount attempt finished via production or bodily environmental extrade via the utility of engineering solutions. While non-structural mitigation is described as a degree that reduces chance via amendment in human behaviour or herbal tactics with out requiring using engineering structures.

Coppola, (2006) says structural mitigation measures are movements related to or dictating the want for a few shape of construction, engineering, or alteration geared toward decreasing the probability or outcome of danger of harm. Structural mitigation is regularly seemed as a "human controlling nature" attempt while carried out to herbal disasters. Structural measures are commonly highpriced and cowl a huge variety of regulatory, compliance, regulation enforcement, inspection, maintenance, and renewal issues. Although every danger has a fixed of precise structural mitigation movements that may be carried out to its risks, those steps may be grouped in numerous trendy categories. The following structural mitigation is meant i.e. Resistant construction; Building codes and regulatory measures; Relocation Structural modification; Construction of network shelters; Construction of barrier, deflection, or retention systems; Detection systems; Physical modification; Treatment systems; Redundancy in lifestyles protection infrastructure.

While nonstructural mitigation consistent with Coppola, (2006) entails lowering the chance or result of threat via changes in human behaviour or herbal processes, with out requiring using engineered structures. A nonstructural mitigation approach is regularly seemed as a mechanism in which "humans adapt to nature. "Nonstructuralistic mitigation has a tendency to be inexpensive and pretty truthful for groups with little economic assets or era to implement. Here are a few nonstructural mitigation measures i.e. Regulatory measures; Community cognizance and schooling programs; Nonstructural bodily changes; Environmental control; Behavioral modification.

\section{Structural functional}

Disasters can cause adverse impacts for humans. Efforts to reduce the risk of the impact of catastrophic events through disaster mitigation activities. Disaster mitigation depends on cooperation between various elements of the community to work together to reduce the incidence and impact of the disaster. It can be seen from a functional structural view considering that the community is a system consisting of interconnected parts, if one part is damaged or not functioning properly, it will affect the overall structure (Raho, 2007). The main concepts are function, dysfunction, latent function, manifest function, and balance (equilibrium)

According to this theory, society is a social system consisting of elements or parts that are interconnected and converge in balance. Changes that occur in one of the sections will bring changes to the other part. The basic assumption is that any structure in the social system, functional against the other. If it is not functional then that structure will not exist or disappear on its own (Ritzer, 1985). Parsons (1970) also filed assumptions regarding the structural functional as follows:

1. Portions of a system are interdependent and have regular properties.

2. The direction of a system is orderly and balanced

3. The process of movement of a system is orderly and somewhat static

4. Parts of a system are influenced by other parts

5. Boundaries with its environment are strongly guarded by a system of

6. Allocation and itegration are essential procedures important to keep the stability of the device

7. The device has a tendency to move closer to renovation of self-stability and renovation of relationships among elements with the entire device, controlling extraordinary environments and controlling the tendency to extrade the device from outside.

\section{METHOD}

The study uses qualitative approach methods. A method with a thorough understanding of a phenomenon but detail. The data source used is primary data and secondary data. The informant is determined in purposive. The number of all informants involved in this research is 20 
people who have the background as government officials, regional disaster management agency, community leaders, citizens, and community groups. Data evaluation is accomplished with levels particularly whilst gathering statistics and after statistics collection. As for researchers use the validity take a look at with statistics triangulation techniques. Researchers also used an analysis of the skeletal thinking of Talcott Parsons;

1. Integration

2. Adaptation

3. Latency

4. Goal Attaintment

The informant in this study was the one who knew the conditions of the situation in the context of the study. Originating from government officials, the Regional Disaster prevention Agency, community figures, citizens, and civic groups.

\section{RESULTS AND DISCUSSION}

Natural disasters are an unavoidable and lifethreatening event. The most appropriate action is to minimize losses before the disaster occurs. The procedure is mitigation. Individuals or societies in this case are important for understanding the pattern of facing natural disaster threats - involved in any form of disaster (Drabek \& Hoetmer, 1991). It was supported by Dynes and Drabek (1994) that it required theoretical models in the implementation of disaster mitigation derived from local resources rather than local governments - considered more of the "point" of trouble in disaster mitigation. And so, the increase in public knowledge to disaster date management is an important pal ing element. In line with that, the will of the ability of society should also be in the braid with the pattern of adaptability accordingly. It was referred to by Talcott Parsons as one of the realizing support systems of disaster response implementation. Deeper, adaptation in this case is closely related to the aspects of integration, thus giving birth to a "pattern" that occurs in society. These three things become a system that affects the achieved or absence of goal achievement. Here is a further description of Talcot Parsons's approach to functional structural theory :

\section{Integration}

The whole party has a stake in minimizing the impact of natural disasters through preventive action. Aligns principles and contributes to each other. The thing that researchers meet is a program that has been conducted by some parties to counteract disasters. It was discovered that it had been conducted extensions on the part of the BPPD which were directly \& cooperating with village government officials. The reflection on simulation, and the educational of disaster mitigation was made several times on the most impacted region. Another form of contribution is in-depth research by the researcher's or educator's personnel of government agencies and educational agencies. Researchers found that the presence of physical unpreparedness of buildings or houses to potential disasters in particular earthquakes. Most of the citizens' home buildings are not buildings devoted to earthquake resistance. In this hat it looks a need for adjustment or cooperation on the part of residential developers and citizens.

In addition there are activities supporting disaster mitigation awareness by the West Bandung County social services and the Forest Service such as monitoring of landslide prone areas and earthquake faulting, planting of roadside trees as a landslide deterrent, there are signs of avalanche warning and earthquakes at such disaster prone sites, and extension/training of disasters. But training efforts and disaster prevention alone have not been enough. It takes advanced and professional research on the importance of disaster mitigation. Some other parties who contributed to disaster mitigation extension activities were the Joint Tani Group of Pagerwangi Village, LKMD, Taruna Coral of Pagerwangi Village, Community Protection and external Institutions such as the Indonesian Red Cross.

Other sides, the fact of the field suggests that not the whole citizen is getting the socialization of disaster mitigation from the government. More precisely it does not fit into the wildness, as extensions are made to citizens of teenage-adult age. The village government briefly applied for socialization on PAUD but there was never a response. And so, socialization regarding the disaster response action is not thorough.

Other findings suggest that the village government already urged related agencies to carry out thorough socialization but to have different responses. Often the insistence does not get a response. So that it becomes an obstacle in the process of improving public knowledge to disaster mitigation.

On the process, any coordinated element does not miss society as the primary goal of disaster mitigation. Yet the hat often misses. Not well coordinated. This will certainly have an impact on adaptations from society. Acceptance and adjustment will be gambling from how each element is coordinated

In this aspect, each element performs a function based on its own role and tasks that it has. So that when they are integrated and each other complements according to their slate. The hemp line is, integration must include all elements that are considered to be able to impact and understand the condition. So that, when not all elements contribute, there will be obstacles to the societal sociation of disaster mitigation.

As with the community's insistence on the Public Works Service for public road repair and maintenance are mainly road embankments, channels/culverts at disastervulnerable sites. This is reinforced with the large number of badly damaged road facilities even endangering 
residents. It is known that the contributions of the Public Works Service have a fairly vital role.

Each element moves based on its function and capability. Based on findings in the field, there are obstacles in the form of a lack of facilities or inadequate means to support socialization and mitigation. That is, the elements of the society involved do not perform their functions or roles in full. This will have an impact on other aspects. Integration as part of the system when finding tonot-conformity will then affect on other systems.

\section{Adaptation}

The socialization of disaster mitigation was well received by the public. The community adaptation form of initiatives from the PKK Team of Pagerwangi Village which held meetings with cadres at mosques to discuss regarding the potential earthquakes in the residents' residential areas. It is also done by the community group Karang Taruna Pagerwangi Village. Karang Taruna that always conduct activities involving the community in doing disaster response. Karang Taruna also participated in disaster response activities held several times by BPPD. The results of disaster mitigation extensions can be said to go as planned. The results are visible from the support gained from public figures so that it will add to the knowledge of the public regarding natural disasters and more highly trained societies especially disaster response power due to simulation and education, the formation of disaster-reguling civic groups such as . KMPB (Class of Disaster prevention Society), another impact is gotong royong activities for fencing activities, installation of disaster vuknerable signs (warning) and planting of trees at disaster-vulnerable sites.

The problems found in the adaptation aspect are those programs that are less informative to society thereby raising concerns. An example of the installation of disappointment signs by the government in citizen land. There was no prior notice especially to the citizens of landowners who were tipped with the signpost of disappointment. It gives rise to a wide variety of responses. Some are disappointed with the installment of disastrous signs can lower the price of selling the land more than there was no previous discussion from the government. Some did not take dizziness but remained disappointed that there was no notice.

From the matter, socialization is an important factor for the adjustment of society to its environmental conditions. Because from the adjustment stage it then becomes the querying stage. Another field finding is a society that has not been touched by the socialization of disaster mitigation from the government.

Back on the integration aspect where it was found that any element whose role or task was not fully run would impact the adaptation or adjustment of society. In this case, the condition of some societies who are not aware of information regarding the installation of disastrous signs is the result of a lack of integration. From the government it should have undertaken a thorough socialization mainly to landowners regarding the installation of disastervulnerable signs. So that the citizens were not shocked and the adaptation process went smoothly.

Further, the public has not had the physical readiness of the anti-earthquake house. There has been a prior study of the importance of earthquake occupancy. Because of the cause of the emergence of fatalities is the destruction of buildings from earthquakes compared to earthquakes themselves. The field facts mention that some societies know about anti-earthquake occupancy, but they are helpless about the fund issue to renovate their occupancy. As a result, people have a high awareness about mitigating what needs to be done in their environment. This is one form of the process of community adaptation to disaster alertness.

\section{Latency}

According to Parsons, sample upkeep in a gadget can corroborate the walking of gadget harmonization. It goals to preserve the gadget from backing down and staying at its function. Not to diffuse and harm the gadget. The form of pattern maintenance that occurs in the fragrant pagerwangi village is the establishment of social groups (KMPB) that focus on disaster mitigation. Inside are self-sustaining educational activities involving local communities and cooperative activities with government agencies. The KMPB became a link between the public and the government. Typically, the activity is carried out on a scheduled basis and based on bureaucratic procedures.

Another form is the activities of the PKK who always discuss with public figures on the increased vigilance of the people against the threat of natural disasters. Further, activities undertaken such as the development of greening and planting of vegetation. The Pagerwangi Village Society in its efforts has undertaken several disaster mitigation programs. Namely the increased capacity of the fund society faces disaster. Its shapes such as extension and training of disappointment, installation of warning boards, fencing, greening with planting of trees on critical land. . This activity was implemented for a 4-month count from August 2010-November 2010. Where local communities served as organizing parties directed by religious figures, members of cadet coral groups, PKK groups, Community Protectors and village governments.

There are some things that the researcher is concerned about, this pattern of maintenance is the direct impact of pre-occurring adaptation and integration. The pattern that occurs is the target of extension still follows the inequality of the integration aspect and has an effect on adaptation, so it is not exactly targeted and thorough. The pattern is still saklek, although there is an insistence from citizens, but since it has been happening in the run long enough to support with many silent or apathetic societies so that the pattern of extension, socialization is still within that zone alone 


\section{Goal Attaintment}

Disaster mitigation is oriented towards the people's material and material readiness to respond to natural disasters. The community consciously adapts to familiarize themselves with always being alert and able to make decisions quickly when critical (when a disaster occurs).

These things were obtained through a socialization process on disaster mitigation counseling. Collaborate with other elements of society namely government agencies, education and community groups. All of them contribute to each other based on their respective duties and roles. The same goal which is to minimize the impact of losses from natural disasters

\section{CONCLUSION}

Based at the effects of the research, the device imbalance that makes the network has no potential to mitigate and the movement of catastrophe preparedness is due to integration factor, adaptation, latency and purpose attaintment. Inconsistency in the aspect of integration, due to the lack of contributing elements, causing barriers in the process of adaptation of society. Continuing to the adaptation phase, the process of adaptation is highly dependent on how the integration occurs. When external parties socialize unthoroughly and the target is lacking, the result is not all people can adjust well (which is expected). It even raises a bit of distraction because of lack of socialization until the community feels shocked even sidelinned. These two aspects ultimately affect the pattern held by the community. Overall the public is aware of disaster mitigation. However the running pattern indicates a pattern with a zone that does not match the target. More precisely the target set is less thorough. Because it is not an entire society in terms of age and is geographically exposed to disaster mitigation socialization program.

\section{REFERENCES}

Asri, A.K., Herfina, E., , Novita, D., Enira, S., \& Donovan, V.L.D.D. (2016). Dual Mitigation System: Database System Combination of EWS and APRS for Disaster Management (Case Study: Malang Southern Coast). Procedia - Social and Behavioral Sciences, 227, 435-441. doi:10.1016/j. sbspro.2016.06.098.

Chacko, J., Rees, L. P., Zobel, C. W., Rakes, T. R., Russell, R. S. \& Ragsdale, C. T. (2016). Decision support for long-range, community-based planning to mitigate against and recover from potential multiple disasters. Decision Support Systems, 87, $13-25$.

Chou, J.-S., Hsu, S.-C., Lin, C.-W., Lee, C.-J. \& Wei, J.L. (2017). Structural analysis of the relationships between implementing tasks and ex-post effectiveness for disaster mitigation practice in
Taipei City. Sustainable Cities and Society, (34), 1-11. doi.org/10.1016/j.scs.2017.06.002

Coppola, D. (2006). Introduction to International Disaster Management. Oxford: Elsevier

Drabek, T.E. (1986). Human System Responses to Disaster: An Inventory of Sociological Findings. New York: Springer Verlag.

Duncan, A., Parknson, D., Archer, F., Keech, E. (2018). Diversity in Disaster conference: Issues paper. Australian Journal of Emergency Management, 3, $10-27$

Dynes, Russell R. \& Thomas E. Drabek. (1994). The structure of disaster research: Its policy and disciplinary implications. International Journal of Mass Emergencies and Disasters. 12, 5-23.

Guinet, A., Barkaoui, H., Wang, T., \& Dubost, E. (2017). A mitigation tool to protect a home health care structure facing a hydrological disaster. IFACPapers On Line, 50, (1), 4630-4635.

Kaban, P. A., Kurniawan, R., Caraka, R. E., Pardamean, B., Yuniarto, B., \& Sukim. (2019). Biclustering Method to Capture the Spatial Pattern and to Identify the Causes of Social Vulnerability in Indonesia: A New Recommendation for Disaster Mitigation Policy. Procedia Computer Science, 157, 31-37. doi:10.1016/j.procs.2019.08.138

Karashima, K., \& Ohgai, A. (2019). Implementation issues of the planning support tool in Japan: Focusing on urban disaster mitigation. Frontiers of Architectural Research. 8, (4), Pg 483-497 doi:10.1016/j.foar.2019.07.002

Muricho, D.N., Otieno, D.J., Oluoch-Kosura, W. \& Jirström, M. (2018). Building pastoralists' resilience to shocks for sustainable disaster risk mitigation: Lessons from West Pokot County, Kenya. International Journal of Disaster Risk Reduction. 34, 429-435 doi:10.1016/j.ijdrr.2018.12.012

Norris, F.H., Stevens, S.P., Pfefferbaum, B., Wyche, K.F. \& Pfefferbaum, R.L. (2008). Community resilience as a methaphor, theroy, set of capacities and strategy for disaster readiness. American journa of community psychology, 41, (1-2), 127-150

Pancasilawan, R. (2020). Mitigation of Disaster Risk Reduction in Pangandaran Regency. Sosiohumaniora. 22, (2). 214-222. doi. org/10.24198/sosiohumaniora.v22i2.25774

Parsons, T. (1970). The Social System. London: Routledge \& Kegan Paul Ltd. ISBN 0-7100-1931-9.

Pramono, R. (2016). Perspektif Sosiologis Dalam Penanggulangan Bencana. Jurnal Masyarakat \& Budaya, 18, (1), 81-96 
Raho, Bernard. (2007). Teori Sosiologi Moderen, Jakarta: Prestasi Pustaka.

Rajeev, K., Soman, S., Renjith, V. R., \& George, P. (2019). Human vulnerability mapping of chemical accidents in major industrial units in Kerala, India for better disaster mitigation. International Journal of Disaster Risk Reduction, 39, 1-24. doi:10.1016/j.ijdrr.2019.101247

Ramli, S. (2010). Pedoman praktis manajemen bencana (Disaster Manajemen). Jakarta: Dian Rakyat

Ritzer, G. \& Goodman. (2007). Teori Sosiologi Modern, Jakarta: Kencana.

Sanyoto, S. (2014). Pengembangan Jaringan Kerja Mitigasi Bencana Kelompok Masyarakat Penanggulangan Bencana Desa Pagerwangi Kecamatan Lembang Kabupaten Bandung Barat. Jurnal Ilmiah Pekerjaan Sosial, 13, (1), 21-35

UNDP (1992). Tinjauan Umum Manajemen Bencana. Program Pelatihan Manajemen Bencana: Edisi kedua. (http://www.undp.go.id) diakses pada tanggal 01 April 2020)

Widayatun \& Fatoni, Z. (2013). Permasalahan Kesehatan dalam Kondisi Bencana: Peran Petugas Kesehatan dan Partisipasi Masyarakat. Jurnal Kependudukan Indonesia 8, (1), 3-52.

World Bank. (2016). Breaking the link between extreme weather and extreme poverty. https://www. worldbank.org/en/news/feature/2016/11/14/ breaking-the-link-between-extreme-weather-andextremepoverty (diakses pada tanggal 01 April 2020)
Wu, X., Wang, Z., Gao, G., Guo, J. \& Xue, P. (2019). Disaster probability, optimal government expenditure for disaster prevention and mitigation, and expected economic growth. Science of The Total Environment, 709, 1-54. doi:10.1016/j. scitotenv.2019.135888

Yoon, D.K., Kang, Jung Eun., Brody, Samuel D., (2015). A Measurement of Community Disaster Resilience in Korea. Taylor and Francis Group: Journal of Enviromental Planning and Management, 59, 436-460.

Ranawati, N. K. (2019). LIPKHAS GEMPA: Warga Bandung Desak Sosialisasi Potensi Gempa Sesar Lembang. https://www.ayobandung.com/ $\mathrm{read} / 2019 / 08 / 07 / 59915 /$ lipkhas-gempa-wargabandung-desak-sosialisasi-potensi-gempa-sesarlembang (diakses pada tanggal 8 Oktober 2019)

Syafei, F.R.(2019). LIPKHAS GEMPA: Desa Pagerwangi Cegah Dampak Sesar Lembang https://www. ayobandung.com/read/2019/08/07/59925/lipkhasgempa-desa-pagerwangi-cegah-dampak-sesarlembang (diakses pada tanggal 8 Oktober 2019)

Ridwan, M,F. (2020). Tebing Punclut Longsor, BPBD Bandung Barat Usulkan Perbaikan. https://www. republika.co.id/berita/nasional/daerah/19/01/10/ pl3sin423-tebing-punclut-longsor-bpbd-bandungbarat-usulkan-perbaikan (diakses pada tanggal 9 Oktober 2019) 